\title{
THE SCANDINAVIAN INSTITUTE OF AFRICAN STUDIES IN UPPSALA, SWEDEN
}

In zwangloser Folge erhalten an dieser Stelle Institutionen, die für die Entwicklungspolitik und Entwicklungsforschung von Bedeutung sind, Gelegenheit zur Selbstdarstellung. Diesmal geben wir dem Centre for African Legal Development das Wort.

The Scandinavian Institute of African Studies was founded in 1962 to meet the growing demand for information about contemporary Africa in all Scandinavia. Its establishment was linked with the substantial expansion of Swedish development assistance to African countries. For example in 1971 the bilateral assistance alone reached the amount of Swedish Crowns 272.8 million, which was shared by Ethiopia, Tanzania, Kenya, Tunisia, Sudan, Botswana/Lesotho/Swaziland and Zambia. The Scandinavian interest in Africa goes much further back than that of course. As early as in the middle of the eighteenth century it was inspired by people like the famous botanist Carl von Linné and his pupil Adam Afzelius. Afzelius's "Sierra Leone Journals" 1795-6 became one of the most remarkable contributions to the knowledge about Africa in Europe. In this respect an important role was played by the Scandinavian missionary work which led to the establishment of the Finnish mission in Ovamboland, the Danish mission in Nigeria, the Norwegian mission in Madagascar and the Swedish mission in Ethiopia and Tanzania. The history of abolitionism is closely connected with the name of Carl Bernhard Wadström, an abolitionist to the Swedish Court who testified before the British House of Commons Committee on the Abolition of the Slave Trade in 1788 and who was co-author together with August Nordenskiöld of „A Plan for a Free Community Upon the Coast of Africa Under the Protection of Great Britain", published in London in 1789.

Although nominally a Scandinavian institution, the Institute at Uppsala is largely financed by Swedish government funds, in which respect it falls under the Swedish Ministry of Education. The other Scandinavian countries, however, contribute to the Institute's research activities, travel grants and other expenses and are represented on the 12 member Board of Directors of the Institute, which is presided over by the Vice-Chancellor of Uppsala University. The Board determines the policy of the Institute and directs its overall activity. The Institute is thus established as being on an equal footing with that of other independent academic institutions.

The Institute originated as an information and documentation centre. A substantial part of the Institute's budget is allocated to the Library for the purchase of books, periodicals and documents on African politics, social sciences, economics, education, art, law and a great variety of other aspects of modern Africa. As a result, the Institute's Africana is one of the best collections of writings, comprising nearly 14,000 volumes. Perhaps even more impressive is the acquisition of periodicals amounting to 1,800 . They include not only the established journals on African affairs but also daily papers of around twenty African countries. (They include,

\footnotetext{
"The Institute's publications written in English are distributed in Europe by Almqvist \& Wiksells AB, Gamla Brogatan 26, Stockholm. More detailed information about the Institute's activities can be obtained directly from the Institute: The Scandinavian Institute of African Studies, P. O. Box 345, S-751 O6 Uppsala, Sweden.
} 
for example, the East African Standard of Tanzania, the Morning Post of Nigeria, the Daily Nation of Kenya, the Standard of Tanzania, The Ghanaian Times of Ghana, etc.) These and numerous pamphlets and brochures considerably facilitate a close follow-up of the internal developments of each African country. Accessions are recorded, along with the Africana accessions, to other research libraries in Scandinavia in the Institute's periodical "Africana in Scandinavian Research Libraries" which appears three times a year. The library staff daily deals with many enquiries by letter and telephone, provides materials for scholars and compiles bibliographies for persons with special interests, in addition to its duties of assisting visitors to the Library, which average 350 persons per month.

In the course of the ten years of its existence, the Institute besides fulfilling its original functions has developed more and more into an important research institution with a fine record of publications. The latest publication „Reporting Africa in African and International Mass Media", edited by one of the Institute's researchers Dr. Olov Stokke of Norway, appeared in 1971. The book is based on the proceedings of an international seminar held in Helsinki in October 1970, where journalists and scholars from Africa, Scandinavia, West and East Europe and Canada discussed the role and status of mass media in Africa. The publication is the last one in the series of similar ventures which resulted from the seminars held on a variety of topics: Development and Adult Education in Africa, (1964) Refugee Problems in Africa, (1966) African Boundary Problems, (1968) and Co-operatives and Rural Development in East Africa, (1970). The 1972 seminar in October will deal with the problems of the land-locked countries in Africa. Other publications of the Institute include "The Writer in Modern Africa" edited by the Swedish author Per Wästberg, „Libraries in East Africa“ edited by the Institute's Chief Librarian Anna-Britta Wallenius, and "Scandinavian Development Agreements with African Countries".

An important feature of the Institute is the research grants awarded annually to the students in African affairs from the Scandinavian universities. An average of ten researchers share a total amount of Swedish Crowns 100,000 allocated to this purpose every year, and enables them to carry out field studies in Africa and complete their research projects. Some of the results of these studies are published by the Institute in a mimeographed series called Research Reports, which include such titles as "Land Tenure - Social Organization and Structure", "The Traditional Foods of the Central Ethiopian Highlands“, and "Some Theoretical and Methodological Aspects of the Study of African Urbanization".

More recently the Institute together with the Swedish International Development Agency and the Ministry of Education is co-operating in producing concise handbooks on individual countries in the forefront of the Scandinavian interest, to be used as textbooks in schools. The first book of this kind on Ethiopia appeared in 1971 which is to be followed by Zambia, Tunisia, Kenya, Uganda, Angola-Mozambique, Botswana, Lesotho and Swaziland in 1972.

The Institute is also expanding its activities in the educational field. The most important activity at the present time is the project for teachers on joint courses with the Swedish International Development Agency. The project is aimed at the broadening of teaching on developing countries in general, and Africa in particular.

The modern duplicating and technical equipment of the Institute, enables the Institute to keep-up with the rising demand for more educational materials for 
schools, courses and lectures, some of which are organised and also given by members of the Institute to a variety of audiences in Scandinavia. The staff of the Institute is relatively small, being only sixteen persons including two senior researchers, and the need for expansion has been felt for some time.

ZdeneK ĆervenKa 